\title{
O sonho da interpretação na arqueologia de Foucault
}

\section{The Dream of Interpretation in Foucault's Archeology}

\author{
* Tomás Mendonça da Silva Prado
}

\begin{abstract}
Resumo: Este artigo procura demonstrar as bases no pensamento de Foucault que o levaram a elaborar o conceito de arqueologia e, além disso, busca reconhecer os seus limites. Para isso, procuramos apresentar as principais interlocuções teóricas do filósofo no início de suas investigações e as constatações que, mais tarde, geraram a necessidade de reelaborar tal conceito. Entre as conclusões deste estudo, destacamos a sugestão de que a concepção alegórica de linguagem sustentada naquele período é formalmente semelhante à estrutura do pensamento metafísico e, como tal, precisou ser abandonada por Foucault como tentativa de encontrar uma forma original de reflexão filosófica.
\end{abstract}

Palavras-chave: Foucault. Arqueologia. Linguagem. Interpretação. Sonho.

\begin{abstract}
This article seeks to present the foundations in Foucault's thought that led him to elaborate the concept of archeology and, in addition, try to recognize its limits. To achieve this, we present his main theoretical dialogues at the beginning of his investigations and the reasons that made necessary to reframe that concept later. Among the conclusions of this study, we suggest that the allegorical conception of language, that was sustained over the period, is formally similar to the structure of metaphysical thought and, as such, is abandoned by Foucault as an attempt to create an original philosophical reflection.
\end{abstract}

Keywords: Foucault. Archeology. Language. Interpretation. Dream.

\footnotetext{
* Doutor em Filosofia (PUC-Rio), com experiência de pesquisa sanduíche na Université Paris 1 Panthéon-Sorbonne, França. Professor do Departamento de Filosofia da Universidade São Judas Tadeu (USJT), em São Paulo.<tomprado@uol.com.br>.
} 


\section{Introdução}

obra de Michel Foucault, já no primeiro de seus escritos publicados, - Isurpreende-nos por suas torções, por dedicar-se, para além da realidade à qual se atém toda ciência positiva, também ao universo onírico. O tema não é alheio aos compromissos do futuro. Ele deixará a marca de que, da realidade empírica, o que mais interessa são os restos. Quando o sonho perder-se como objeto de estudos teóricos, ainda assim nenhum arquivo merecerá os cuidados do filósofo se não puder evocá-lo. Foucault vai velar os sonhos em lugares escusos, além do inconsciente, sobre as prateleiras empoeiradas onde as bibliotecas preservam o que foi esquecido.

Não se trata, portanto, com seu arcabouço teórico e sua erudição, de fazer de discursos rememorados, tantas vezes de autores desconhecidos e homens infames, uma arma contra quimeras. Articulado à ideia de "experiência", noção cara ao pensamento dos últimos dois séculos, o sonho atravessa-nos quando estamos distraídos da razão vigilante. E, quando parecer faltar, talvez desprestigiado por influências cartesianas, o sonho estará na experiência. A cada vez que dela falar-se - a "experiência da loucura", a "experiência literária", "a experiência da ordem", as "experiências-limite" - lá o encontraremos: a um só tempo, a positividade empírica e os seus restos; o que salta aos olhos e o que os assalta.

À parte do sono, em que as coisas reivindicam um desígnio natural, o sonho encontra a verdade na abrupta transfiguração de um despertar.

\section{A sobredeterminação do sonho}

Antes daquelas dedicadas aos arquivos, Foucault iniciou suas investigações pelo trabalho dedicado ao sonho. O primeiro texto, publicado em março de 1953, é a introdução ao livro O sonho e a existência, de Biswanger, por ocasião de sua tradução para o francês. Nele, vê-se o intuito de nutrir a psiquiatria de uma relação entre duas outras disciplinas, a antropologia e a fenomenologia, e de compreender, mais especificamente, as razões pelas quais o Dasein (ser-aí) - conceito proposto em Ser e tempo, por Heidegger, para analisar as implicações do homem ao mundo - deve ser pensado antropologicamente, o que significa pela "ciência dos fatos". ${ }^{1}$

A elaboração fenomenológica do conceito de Dasein contrapõe-se, na filosofia, a determinações do sujeito anteriores à sua lida com as coisas, em favor da existência fatual. A proposta de Biswanger de

1 FOUCAULT, M. "Introdução (in Biswanger)", Ditos e escritos, v. 1, 2010, p. 72. 
relacionar a fenomenologia à visão antropológica, uma vez abraçada por Foucault, é o primeiro respaldo ao que dissemos sobre o seu interesse pela abordagem empírica ou positiva da realidade. Falta resgatar os restos que sugerimos ser o seu interesse maior. A questão é como o sonho, que habitualmente tomamos como produção de uma faculdade subjetiva, a imaginação, insere-se na "ciência dos fatos", e como ele pode ser assimilado ao mundo no qual cada um de nós se descobre lançado. Em suas palavras: "Não será um despropósito querer circunscrever o conteúdo positivo da existência em um de seus modos menos inseridos no mundo?"2 Essa pergunta ecoará ao longo de toda a sua obra. Desapegado conceitualmente da referência onírica, e de Biswanger, ele tratará ainda de outras "experiências-limites". Por exemplo: a "loucura" e os "interditos sexuais", conteúdos positivos na existência embora marginais no mundo.

Atendo-nos ao sonho, a argumentação sobre a sua relação com o mundo avançará reportando-se criticamente a outra mais célebre. A psicanálise de Freud torna-se alvo de ataques polêmicos quanto aos seus procedimentos de interpretação, os quais serão confrontados com a proposta de interpretação da fenomenologia de Husserl. Teremos duas compreensões de linguagem como consequência de duas formas de interpretação. Tomando-as como base, Foucault dá o primeiro passo na constituição de seu próprio pensamento.

A psicanálise não explora senão uma dimensão do universo onírico, a do vocabulário simbólico, ao longo da qual se faz a transmutação de um passado determinante para um presente que o simboliza; a polissemia do símbolo com frequência definida por Freud como 'sobredeterminada' complica, sem dúvida, esse esquema e lhe dá uma riqueza, dela atenuando o arbitrário. ${ }^{3}$

Não é certo que a psicanálise explore unicamente a dimensão simbólica do sonho. Freud chega a afirmar que, quando se interpreta um sonho, nunca se está inteiramente seguro se ele "deve ser tomado num sentido positivo ou negativo"; se ele "deve ser interpretado historicamente (como uma lembrança)"; se ele "deve ser interpretado simbolicamente"; ou se sua interpretação deve depender do "palavreado" com o qual o sonho é apresentado. ${ }^{4}$ Lacan é o responsável, na psicanálise, pelo primado do

2 FOUCAULT, M. "Introdução (in Biswanger)", Ditos e escritos, v. 1, 2010, p. 74.

3 Ibid., p. 107.

${ }^{4}$ FREUD, S. "A interpretação dos sonhos" em Obras psicológicas completas de Sigmund Freud, v. V, 1973, p. 363. 
símbolo. ${ }^{5}$ A esse momento na trajetória de Foucault, porém, a proposta psicanalítica - considerada, sobretudo, com base em $A$ interpretação dos sonhos (1900) - é tomada como restrita e arbitrária devido ao modo com que trata a linguagem simbólica. Mas o que é um símbolo? Um símbolo relaciona dois universos, propõe o encontro de duas realidades apartadas - uma que é imagem e a outra que é sentido. A psicanálise teria a ambição de utilizar algumas fórmulas para ler todos os símbolos, constituindo um "vocabulário simbólico" que fosse o retrato de todos os homens e não o retrato de si mesma. Ela traria clareza a algo como a fala coerente das imagens oníricas de todos, e não a sua própria fala. ${ }^{6}$

Vejamos o caso da escuta com a qual o psicanalista desvenda o delírio paranoico. Ela inverte os efeitos do recalque, que é responsável por dissimular os desejos do sujeito à sua consciência constrangida. Uma vez dominada a lógica da inversão, o desejo antes não assumido, que não era sequer conhecido, é então revelado. A "armadura mágica do delírio paranoico", como diz Foucault, abre-se quando o psicanalista endireita o que o recalque havia invertido, e o desejo consequentemente advém por uma fala exatamente contrária àquilo que a imagem havia mostrado.

'Eu não o amo, eu o odeio'; 'não é ele que eu amo, é ela que eu amo porque ela me ama'; 'não sou eu que amo o homem, é ela que o ama'; declinações cuja forma primeira e o grau semântico mais simples são: 'Eu o amo', e cuja forma última inteiramente oposta, adquirida através de todas as flexões da contradição, se enuncia: 'Eu não amo nada nem ninguém, eu só amo a mim'. ${ }^{7}$

O problema, para Foucault, consiste em confiar-se demasiadamente na existência de um sentido primeiro que teria sido transfigurado.

\footnotetext{
5 "Os símbolos efetivamente envolvem a vida do homem numa rede tão total que conjugam, antes que ele venha ao mundo, aqueles que irão gerá-lo 'em carne e osso'; trazem em seu nascimento, com os dons dos astros, senão com os dons das fadas, o traçado de seu destino; fornecem as palavras que farão dele um fiel ou um renegado, a lei dos atos que o seguirão até ali onde ele ainda não está e para além de sua própria morte". LACAN, J. "Função e campo da fala e da linguagem" em Escritos, 1998, p. 280.

${ }^{6}$ Podemos dar alguns exemplos: "A representação típica - isto é, regular - da figura humana é uma casa"; "As casas com paredes lisas representam homens, e aquelas com saliências e sacadas, em que é possível segurar-se, representam mulheres"; "Os pais aparecem nos sonhos como imperador e imperatriz, rei e rainha ou outras personagens respeitadas"; "os irmãos e as irmãs: estes são simbolizados como pequenos animais ou bichinhos"; "O nascimento é quase que invariavelmente por algo que tem uma conexão com a água"; "Morrer é substituído, nos sonhos, por partir, por viajar de trem". FREUD, S., "Simbolismo nos sonhos" em Obras psicológicas completas de Sigmund Freud, v. XV, 1973, p. 183-184.

7 FOUCAULT, M. "Introdução (in Biswanger)", em Ditos e escritos, v. 1, 2010, p. 79.
} 
Sendo o símbolo "polissêmico", ele deveria, no lugar de resguardar uma origem tão secreta quanto "determinante", estar aberto a outras leituras. Mas um símbolo polissêmico, que aproxime não duas, mas múltiplas realidades, permanece símbolo? De um lado, Foucault restringe a sua visão da psicanálise aos primeiros trabalhos de Freud e faz com que toda a proposta psicanalítica passe pelo modelo do simbolismo, porém, de outro, sugere, com razão, que esse modelo é o maior desafio para a interpretação psicanalítica - e o será até o pleno reconhecimento da "sobredeterminação" da parte de Freud ou até o dia em que Lacan afirmar, com outras palavras, que uma significação não remete senão a outra significação. ${ }^{8}$ Haveria uma espécie de autoridade arbitrária por trás da proposta psicanalítica em seus primeiros dias, a qual Foucault chega a referir-se como uma "mitologia teórica", que selecionaria, entre a multiplicidade de sentidos possíveis de uma imagem onírica, um ao qual ela vem conferir privilégio, confiando em uma determinação natural, uma origem metafísica. A interpretação na experiência da psicanálise freudiana não albergaria nenhuma complexidade diante do mundo e tampouco diante da experiência particular do intérprete. Conclusão provisória, mas nem por isso menos radical: "A psicanálise jamais conseguiu fazer falar as imagens." 9

Foucault censura Freud por buscar no símbolo uma forma de fazer falar as imagens, mas o desafio - fazer falar as imagens - deve perseverar. A fenomenologia de Husserl serve a esse ponto como mais profícua referência. Ao contrário do procedimento psicanalítico, ela propõe um tipo de interpretação que, no lugar de um trabalho brutal sobre o símbolo, tomaria a prudência de seguir o "indício".

Vejo buracos na neve, espécies de estrelas regulares, cristais de sombra. Um caçador aí verá os rastros frescos de uma lebre. Essas são duas situações vividas; seria vão dizer que uma comporta mais verdade do que a outra; mas, no segundo esquema se manifesta a essência da indicação, no primeiro, não. É para o caçador, somente, que a pequena estrela escavada na neve é um signo. ${ }^{10}$

Vemo-nos diante de duas compreensões da linguagem: aquela do símbolo psicanalítico e agora a do indício fenomenológico. $\mathrm{Na}$ fenomenologia, não nos é apresentado um filtro universal capaz de fazer

\footnotetext{
8 "Vocês se engajarão em vias sempre sem saída, o que se vê muito bem nos impasses atuais da teoria analítica, se ignorarem que a significação não reenvia nunca senão a ela mesma, isto é, a uma outra significação". LACAN, J. O Seminário, livro 1 Os escritos técnicos de Freud, 1983, p. 270.

9 FOUCAULT, M. "Introdução (in Biswanger)", em Ditos e escritos, v. 1, 2010, p. 80.

${ }^{10}$ Ibid., p. 82.
} 
falar por um só mecanismo, como a inversão do recalque, o sentido último de qualquer imagem. O indício, ao contrário do símbolo, não carrega em si a promessa de sua decifração cabal. O indício é sempre contingente, pois está submetido à experiência de quem se apresenta a lê-lo e a comentá-lo - a significá-lo. Se há uma essência própria ao método fenomenológico, tal como o vemos tanto em Husserl quanto em Heidegger, ela consiste em que a interpretação dos indícios não seja nem arbitrária, nem resultado direto das faculdades do sujeito, nem uma lei social. Compreendemos, a todo instante, indícios indeterminadamente diversos com base em condições mundanas que se apresentam às nossas vidas. Por exemplo, habitar as redondezas da floresta e aprender a praticar a caça com destreza. Finalmente, é a forma como compreendemos os indícios que fala do intérprete que somos.

Entretanto, como tudo isso se aplica ao sonho? E o que as interpretações de Foucault da psicanálise e da fenomenologia dizem a seu respeito? Por um momento, Biswanger parece ter sido esquecido, mas assim vemos surgir referências que, ainda mais que Biswanger, permanecerão significativas para a obra do filósofo. Foucault recorda, em seu lugar, Novalis, autor do romantismo alemão no século XIX: "O sonho é a imagem primeira da poesia, e a poesia, a forma primitiva da linguagem, a 'língua materna do homem'. O sonho, assim, está no princípio mesmo do devir e da objetividade."11 Ele lembra Victor Hugo, em uma passagem de Os miseráveis: "Nossas quimeras são o que melhor se parece conosco",12 reverencia Aristóteles: "o valor do sonho está ligado à calma da alma, a esse sonho noturno no qual ela se desprende da agitação do corpo, nesse silêncio, ela se torna sensível aos movimentos mais tênues do mundo"; ${ }^{13}$ e presta reconhecimento à toda a Antiguidade, em que "o homem sabe que no sonho ele se encontra com o que ele é e com o que ele será; com o que ele faz e com o que ele fará; ele ali descobriu esse nó que liga sua liberdade à necessidade do mundo". ${ }^{14}$

Em todas essas referências históricas que servem de argumento para aproximar o sonho da existência mundana, satisfazendo pela erudição a sua exigência de pensar sobre bases positivas, Foucault dá o primeiro passo rumo à sua própria heterotopia: lugar não tanto da dimensão histórica do sonho quanto da dimensão onírica da história.

\footnotetext{
${ }^{11}$ NOVALIS in FOUCAULT, M. "Introdução (in Biswanger)", em Ditos e escritos, v. 1, 2010, p. 101.

${ }^{12}$ VICTOR HUGO in FOUCAULT, M. "Introdução (in Biswanger)", em Ditos e escritos, v. 1, 2010, p. 99.

${ }^{13}$ ARISTÓTELES in FOUCAULT, M. "Introdução (in Biswanger)", em Ditos e escritos, v. 1, 2010, p. 94.

${ }^{14}$ FOUCAULT, M. "Introdução (in Biswanger)", em Ditos e escritos, v. 1, 2010, p. 93.
} 


\section{A sobredeterminação da história}

Somos censurados, nessa pontuação, de haver não somente ultrapassado a letra dos textos freudianos e husserlianos, mas ainda de haver inventado inteiramente uma problemática que Biswanger jamais formulou, e cujos temas não estão nem mesmo implícitos em seus textos. Esse agravo nos pesa pouco, porque temos a fraqueza de acreditar na história mesmo quando se trata da existência. (...) Encontrar-se-á em seus textos o problema que ele se colocou; nós queríamos, de nossa parte, extrair aquele ao qual ele respondeu. ${ }^{15}$

Foucault diz acreditar na história como se lhe dissessem que, em seu trabalho, ela não passa de um sonho. Censura que não recairia sobre um trabalho dedicado apenas aos textos; censura contra aquele que ultrapassa a letra com o risco de perder-se; censura que tantas vezes virá e que algumas vezes procede, senão pela infidelidade aos arquivos históricos, então pela infidelidade às suas próprias análises.

A polêmica sobre as formas de voltarmo-nos à história ultrapassa-o. Há muito ela faz-se presente na relação entre história e filosofia, sobretudo tomando-se por base Leopold Ranke, autor alemão do século XIX, considerado o pai da história moderna e para quem ela não deve julgar o passado, mas somente mostrar o que ocorreu. Hegel esteve ciente da acusação contra os filósofos. A despeito do modo como o seu pensamento poderia, talvez mais do que qualquer outro, representar a posição dos filósofos nesse conflito, em 1830, ele afirma: "Entre aqueles que possuem uma grande autoridade e que confiam no que se denomina o estudo das fontes, há quem faça o que se censura nos filósofos, a fabricação de fabulações a priori na história". ${ }^{16}$ Hegel afirma, contra as fábulas, que a fidelidade às análises históricas é imprescindível e chega a discriminar em Filosofia da história quais métodos seriam mais e menos fiéis aos fatos, mas jamais admitirá que em vista dessa preocupação possa-se abdicar da reflexão conceitual com a qual trabalha a filosofia.

A polêmica remete, em sua origem, a dois filósofos do século XVIII: Vico, na Itália, e sua compreensão de que o homem não conhece senão aquilo que produz, ou seja, a sua própria história; e Voltaire, na França, para quem cabe à filosofia filtrar o que na história é-nos útil. Há, nos três filósofos, paradoxalmente, a mesma pretensão à cientificidade do

\footnotetext{
${ }^{15}$ Ibid., p. 87.

${ }^{16}$ Trad. livre. Encontramos em francês: "Parmi ceux qui possèdent une grande autorité et qui s'accordent tout le crédit en raison de ce que l'on dénomme l'étude des sources, il y en a qui font ce qu'ils reprochent aux philosophes, à savoir fabriquer des affabulations a priori dans l'histoire." HEGEL, G. "Les introductions manuscrites" em Introduction à la philosophie de l'histoire, 2011, p. 49-50.
} 
pensamento, critério que os uniria à historiografia de Ranke. Vemos um exemplo nesta passagem do prefácio da Fenomenologia do espírito, de Hegel: "Colaborar para que a filosofia se aproxime da forma da ciência - da meta em que deixe de chamar-se amor ao saber para ser saber efetivo - é isto o que me proponho." ${ }^{17}$ No entanto, não satisfeita com os resultados de tais empreendimentos filosóficos aspirantes à cientificidade, a crítica de Ranke acusa a filosofia de sempre entulhar a história com suas produções de conceitos, com suas sistematicidades prévias, concernentes, em geral, a uma "história universal", e jamais permitindo a ela revelar-se em sua multiplicidade e imprevisibilidade. Vemos em Foucault um espírito que quer pôr-se mais próximo a Ranke, também respeitando as singularidades das fontes empíricas sem submetê-las a um todo, portanto, em detrimento da noção de "história universal".

Foucault não pretende que a história seja a confirmação de um sistema conceitual concebido a priori, submetido à metafísica, mas, se a censura da parte dos historiadores procede sob essa ótica é porque ele não adere de todo à pretensão da neutralidade científica. Afinal, é preciso problematizar a própria historicidade das ciências. Da tensão entre esses dois compromissos opostos, nasce, desenvolve-se e distingue-se o seu pensamento. $\mathrm{O}$ que se censura em Foucault é ele ter tratado a história não somente como dados materiais a reunir, encontrando neles imagens a interpretar. Mas o que, ao contrário, é preciso nele admirar é que sejam imagens elaboradas o suficiente para fazerem-nos questionar a realidade que imaginávamos ser a mais sóbria.

A citação do texto de 1953, vista anteriormente, poderia ser assumida como o marco inicial do seu trabalho. Há nela, além do pressuposto de censura contra apropriações e mudanças de posição, uma implicação pessoal - elementos que serão recorrentes em sua postura filosófica. Fora o aspecto estilístico, trata-se ali também do método que será por ele possivelmente o mais utilizado: remeter a produção de um saber à circunstância na qual ele inscreve-se; devolvê-lo às suas raízes até então desconhecidas. É por este espaço de penumbra, o qual ele supõe envolver as singularidades dos registros históricos, que se configurarão as imagens de seu pensamento, por exemplo, "o nascimento da clínica". Elas não surgem, portanto, de imediato, unicamente das evidências, sendo o resultado de um trabalho sobre os registros, da interpretação que lhes é dirigida. Diversas vezes as suas interpretações precisarão retornar às imagens que foram constituídas. Afinal, a imagem histórica, à semelhança do procedimento exigido para a dimensão onírica, permite e, por vezes, requisita uma reinterpretação. Se Biswanger dedica-se à produção

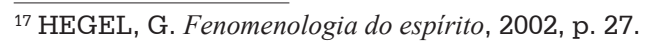


de um novo saber psiquiátrico pelo encontro da fenomenologia com a antropologia, a circunstância que, segundo Foucault, está primeiramente em questão nesse encontro é a problematização do método interpretativo, uma espécie de nascimento da interpretação - circunstância analisada em 1953 e que será novamente tomada, reinterpretada, em um colóquio de 1967, intitulado "Nietzsche, Freud, Marx".

Na segunda ocasião em que Foucault atém-se diretamente à temática da interpretação, ele propõe que o modelo apresentado no fim do século XIX pelos três célebres pensadores impõe condições que vigoram ainda em nossos dias. Antes de apresentá-las, cabe observar que há também ali, como na análise de 1953, uma advertência contra a forma de interpretação que remete uma imagem a um sentido unívoco e originário: "A morte da interpretação é acreditar que há signos, signos que existem primeiramente, originalmente, realmente, como marcas coerentes, pertinentes e sistemáticas." 18 No entanto, agora não será mais a psicanálise a representante dessa lógica binária, referida a uma suposta realidade primeira e cuja proposta causa-lhe tanta aversão. Freud não é mais, em 1967, uma referência a ser superada, mesmo sendo $A$ interpretação dos sonhos ainda a sua obra mais citada. Aquilo que havia sido reconhecido na autocrítica freudiana como "sobredeterminação" do sentido não é mais tomado como mero atenuante dos problemas da teoria psicanalítica, mas como o que há de mais importante nela - talvez a essência de todo o modelo de interpretação que Foucault agora identifica ser oriundo do século XIX.

Vejamos as características apresentadas no colóquio de 1967 da hermenêutica desde Nietzsche, Freud e Marx.

A primeira é que a interpretação será sempre, desde então, interpretação através do 'quem'; não se interpreta o que há no significado, mas, no fundo, quem colocou a interpretação. O princípio da interpretação nada mais é do que o intérprete. [...] A segunda consequência é que a interpretação tem sempre que interpretar a si mesma, e não pode deixar de retornar a si mesma. ${ }^{19}$

No século XIX, a interpretação torna-se uma tarefa infinita, obrigada a voltar-se sobre si mesma. A cada compreensão cabe a interrogação: o que faz com que as coisas sejam tomadas de tal maneira e não de outra? Sendo o princípio da interpretação o intérprete, a questão poderia ser posta também da seguinte forma: por qual razão particular de sua existência o intérprete compreende as coisas de um modo e não de outro?

\footnotetext{
${ }^{18}$ FOUCAULT, M. "Nietzsche, Freud, Marx" em Ditos e escritos, v. 2, 2008, p. 50
}

${ }^{19}$ Ibid., p. 49 
É, aparentemente, na existência do intérprete que se encontra o critério contra o relativismo sem fim da interpretação.

Supomos, neste ponto, que a figura do intérprete deve remeternos novamente à consciência transcendental de Husserl e ao Dasein de Heidegger, enfim, à fenomenologia mais do que a qualquer outro modelo, posto que o homem surge ali como aquele para quem a imagem é sempre uma abertura, um indício voltado ao sentido encontrado em sua vida. Não há, no colóquio de 1967, nenhuma referência direta aos dois filósofos alemães, o que não significa que a fenomenologia não seja posta ali em questão. A referência indireta, que encontramos pelos usos terminológicos, revela um tratamento surpreendentemente hostil. Se, em 1953, tratava-se de encontrar no conceito husserliano de "indício" a fértil alternativa ao "vocabulário simbólico" psicanalítico, não apenas vemos agora salva a psicanálise como vemos surgir a linguagem husserliana como aquela a ser superada. Conhecemos na "Introdução (in Biswanger)" um exemplo a partir do qual se conclui que "é para o caçador, somente, que a pequena estrela escavada na neve é um signo". Agora, Foucault afirma que "a morte da interpretação é acreditar que há signos". E ainda: "Uma hermenêutica que se restringe de fato a uma semiologia, acredita na existência absoluta dos signos: ela abandona a violência, o inacabado, a infinitude das interpretações, para fazer reinar o terror do indício e suspeitar da linguagem." ${ }^{20}$ Se o indício, ainda mais do que o signo, foi, para Foucault, o conceito-chave da hermenêutica fenomenológica, vemos o confronto antes voltado à psicanálise dirigido agora à fenomenologia.

Há questões presentes em obras muito importantes, como As palavras e as coisas, de 1966, que se interpõem a essa reviravolta. Parte do aparato conceitual até então desenvolvido é distribuído na história pela decupagem de espaços gerais do saber segundo, a cada vez, uma epistémê específica: Renascimento, época clássica ou modernidade. As questões que se impõem à modernidade, como o surgimento do paradigma da interpretação que é, em 1967, atribuído a Nietzsche, Freud e Marx, passaram no ano anterior pelo reconhecimento das suas implicações e diferenças com a interpretação no Renascimento: "A linguagem do século XVI - entendida não como um episódio na história da língua, mas como uma experiência cultural global - foi sem dúvida tomada nesse jogo, neste interstício entre o Texto primeiro e o infinito da interpretação." 21 Mas o importante agora é constatar as sutilezas do confronto entre esses dois textos, de 1953 e 1967. Seria um problema mais terminológico do que metodológico? É justo supor rompimentos quando,

\footnotetext{
${ }^{20}$ Ibid., p. 50.

${ }^{21}$ FOUCAULT, M. As palavras e as coisas, 2002, p. 57.
} 
de uma forma ou de outra, estão presentes as mesmas referências? Já seria problemática a apropriação feita tanto de Nietzsche quanto de Marx, para quem - como sugere Vattimo, em determinado ponto do colóquio de $1967-$,22 $^{22}$ materialismo histórico e a luta de classes deveriam servir de limite ao relativismo da interpretação infinita. Mas nos atenhamos também à rica trama da linguagem que Foucault identifica entre a psicanálise e a fenomenologia.

\section{A origem da arqueologia}

Em 1953, Foucault afirmara: "A fenomenologia conseguiu fazer falar as imagens; mas ela não deu a ninguém a possibilidade de empreender sua linguagem." $23 \mathrm{O}$ que parece uma crítica poderia ser compreendido como elogio: a fenomenologia conseguiu fazer falar as imagens sem conceder a ninguém um domínio total sobre a linguagem, sem encerrá-la em um sistema hermético, na medida em que a linguagem advém em referência a uma existência particular situada no mundo e permanecerá aberta enquanto a existência à qual a linguagem reporta-se estiver também aberta a novas realizações. Tratava-se de fazer despertar a existência, pois somente assim a linguagem, como esfera alternativa à metafísica, seria também desperta. "Se no sono a consciência adormece, no sonho, a existência se desperta" 24 - afirma Foucault. Tratava-se de reconhecer que o problema da interpretação surge ao mesmo tempo em que a filosofia problematiza, mais do que o inconsciente, a existência, porque esta é a forma como partiríamos da experiência mundana em detrimento das inferências metafísicas. Tratava-se, em suma, conforme o modo como Foucault aborda Biswanger, de encontrar no sonho e na interpretação o despertar da existência e da linguagem.

Essa inscrição do sonho no mundo, o fato de que o sonho desperta a existência para o mundo talvez bastasse para justificar a hipótese inicialmente conjecturada de que há, no pensamento de Foucault, o sonho antes do arquivo, pois a relação do sonho com a existência é o mais próximo que até então - fora do materialismo histórico e da historiografia científica - poder-se-ia chegar da positividade na história, da antropologia como "ciência dos fatos". É esse o diagnóstico de Biswanger assumido então por Foucault. Mas isso não é tudo o que se passou em seu plano, pois havia desde o início uma insatisfação.

\footnotetext{
22 Vattimo afirma: "Estou inteiramente de acordo com você no que se refere a Nietzsche. Mas, em relação a Marx, não há necessariamente um ponto de chegada?". FOUCAULT, M. "Nietzsche, Freud, Marx" em Ditos e escritos, v. 2, 2008, p. 51.

${ }^{23}$ FOUCAULT, M. "Introdução (in Biswanger)" em Ditos e escritos, v. 1, 2010, p. 86.

${ }^{24}$ Ibid., p. 104.
} 
Não é porque não se pode encontrar na fenomenologia um vocabulário que dê conta de todas as imagens, que não haja nela a promessa de submeter a imagem a um sentido original: o sentido de uma existência. Ao mesmo tempo, o que ele ressente-se de não ter encontrado na fenomenologia não é o modo como a relação com o mundo condiciona as expressões do homem, mas um modo de o mundo expressar a si mesmo, de expressar a sua história para além da compreensão de uma só uma existência. Se a fenomenologia afirma que o sentido pertence sempre a uma compreensão, que lhe dá suas condições de possibilidade, ela associa a linguagem, segundo Foucault, a uma interioridade - ainda que uma interioridade constituída no mundo. No colóquio de 1967, Foucault dirá que, a partir do século XIX, "os signos foram escalonados em um espaço muito mais diferenciado, segundo uma dimensão que se poderia chamar de a da profundidade, desde que não a entendamos como interioridade, mas, ao contrário, como exterioridade." 25 Autêntica ou inautêntica, nenhuma existência seria capaz de fazer falar as imagens da história, mas somente as imagens que se voltam, conforme Husserl, aos atos de sua consciência interior, e conforme Heidegger, ao Dasein (ser-aí). De fato, encontramos uma passagem que o confirma em Ser e tempo: (a fenomenologia) "Trata-se de uma hermenêutica que elabora ontologicamente a historicidade do Dasein como condição ôntica de possibilidade da história fatual." 26

De onde, então, a ruptura com a fenomenologia? Um trabalho sobre indícios que remetam sempre às vivências tornaria a história uma construção demasiado subjetiva, nada além de um sonho pessoal. A mesma crítica faz-se a Heidegger por pretender sustentar a visão da história sobre a analítica do Dasein. Em suma, é a "fraqueza de acreditar na história" que põe abaixo, para Foucault, o valor da existência para a linguagem e, com isso, o valor da fenomenologia. Heidegger antevira-o, abandonando depois de Ser e tempo a análise do Dasein e dedicando-se a pensar as possibilidades de um vínculo diferente da linguagem com a história - alternativa que será, então, marcada pelo conceito de "saga". ${ }^{27}$

Foucault procurará uma alternativa por seus próprios meios, e surpreende-nos ver que o seu caminho passará por uma reconsideração da proposta psicanalítica. O colóquio de 1967, no qual Nietzsche e Marx parecem servir-lhe mais do que tudo de pretexto para acertar as contas com Freud, depois das inúmeras críticas que lhe foram endereçadas, é

\footnotetext{
${ }^{25}$ FOUCAULT, M. "Nietzsche, Freud, Marx" em Ditos e escritos, v. 2, 2008, p. 44.

${ }^{26}$ HEIDEGGER, M. Ser e tempo, 2000, p. 69.

27 "O vigor da linguagem é a saga do dizer enquanto o mostrante. O seu mostrar não se funda num signo. Todos os signos é que surgem de um mostrar, em cujo âmbito e para o qual os signos podem existir". HEIDEGGER, M. A caminho da linguagem, 2004, p. 203.
} 
central para o esclarecimento da questão. Por estranho que pareça, é em Freud que Foucault encontrará um caminho contra a problemática da interioridade que ele atribui à fenomenologia. Da mesma forma como ele pretendeu um dia encontrar no sonho positividades antropológicas, Foucault tomará dos argumentos um dia formulados contra a psicanálise a medida de objetividade que a este momento necessita para as interpretações que empreende da história.

Voltemos às censuras de 1953, em "Introdução (In Biswanger)".

A psicanálise freudiana do sonho jamais é uma apreensão do sentido. O sentido não aparece para ela, através do reconhecimento de uma estrutura de linguagem; mas ele deve extrair-se, deduzir-se, adivinhar-se a partir de uma fala tomada por ela própria. E o método da interpretação onírica será muito naturalmente aquele que utilizamos para encontrar o sentido de um vocábulo, em uma língua da qual ignoramos a gramática: um método de cotejo, tal como o utiliza a arqueologia para as línguas perdidas, um método de confirmação tanto pela probabilidade como pela decifração dos códigos secretos, um método de coincidência significativa como nas semânticas mais tradicionais. [...] A análise freudiana nunca retoma senão um dos sentidos possíveis pelos atalhos da adivinhação ou pelos longos caminhos da probabilidade: o próprio ato expressivo jamais é reconstituído em sua necessidade. ${ }^{28}$

Da crítica que, em seu primeiro texto publicado, Foucault articula contra a psicanálise, surge o conceito que se tornará um dos mais importantes e representativos de seu pensamento: arqueologia. Poderíamos questionar se há em seu uso uma diversidade terminológica, persistindo o termo, mas com um sentido diverso. Tudo o que vimos leva-nos a crer que não se trata ainda de uma alteração no sentido do termo, mas de uma reconsideração sobre a importância do que ele representa. Afinal, por muito tempo, a arqueologia procederá de maneira semelhante àquela que vemos ser construída em 1953 a respeito da psicanálise. Que a psicanálise procedesse como uma arqueologia, ou seja, como um "método de cotejo", "um método de confirmação tanto pela probabilidade como pela decifração dos códigos secretos", "um método de coincidência significativa como nas semânticas mais tradicionais", seriam fraquezas que lhe impediriam de promover a "apreensão do sentido", que lhe vetaria "o próprio ato expressivo". Por tais métodos de extração, dedução e até mesmo adivinhação, a psicanálise produziria, de sua arqueologia, outro "vocábulo" que não aquele das "línguas perdidas" - clara referência à análise da "paleontologia linguística" de Saussure,

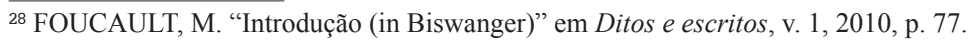


em seu Curso de linguística geral. ${ }^{29} \mathrm{Na}$ ausência do "ato expressivo", o que nela encontramos seria um "vocabulário simbólico". Mas quando toda a atmosfera crítica de sua compreensão da psicanálise perde-se, não somos então levados a crer que haverá, no método de Foucault, em sua arqueologia, as mesmas marcas? Uma vez admitido que o nascimento da interpretação atribuído por Foucault ao século XIX, e no qual ele mesmo ainda se vê inserido, não é senão o nascimento da arqueologia presente tanto na descoberta das línguas perdidas quanto no método psicanalítico, não se esclarece a sua adesão em 1967 àquilo contra o que, em 1953, ele voltava-se?

Chegará o dia em que ele reivindicará novamente a importância dos "atos expressivos" e que a arqueologia já não será a mesma. Ela estará talvez novamente mais próxima da fenomenologia do que da psicanálise, porque o trabalho sobre os arquivos comportará um tanto de descrição mais aparente do que de decifração dos segredos. À diferença desta que vemos agora nascer, surgirá uma arqueologia que será não apenas "um retorno às coisas mesmas", como afirmou Husserl, como se encarregará de "deixar e fazer ver por si mesmo o que se mostra, tal como se mostra a partir de si mesmo", ${ }^{30}$ como afirmou Heidegger. Ao longo de muitos anos e de muitas obras, porém - mais especificamente até o instante anterior a $A$ arqueologia do saber, de 1969 -, como por uma obrigação de retorno à psicanálise pelo fracasso atribuído às limitações do método fenomenológico à existência individual, interpretar, fazer uma arqueologia da história, para Foucault, será precisamente aplicar um método de cotejo, será identificar as coincidências significativas e será, sobretudo, "decifrar os códigos secretos".

\section{A alegoria da alegoria}

Com a análise de dois textos - "Introdução (in Biswanger)", de 1953, e "Nietzsche, Freud, Marx", de 1967 -, juntamos as duas pontas de um possível recorte da obra foucaultiana, o qual costuma ser representado pelo conceito de arqueologia. Leitores experientes desse filósofo observarão que seus comentadores em geral denominam "fase arqueológica" um conjunto que se estenderia até um pouco além desse segundo marco,

\footnotetext{
29 "Ora, não parece que se possa pedir a uma língua ensinamentos desse gênero, e que ela não possa fornecê-los se deve, a nosso ver, às seguintes causas: em primeiro lugar à incerteza da etimologia. [...] Os significados das palavras evoluem. [...] A possibilidade de empréstimos é um terceiro fator que perturba a certeza. [...] Isto não quer dizer que não se possam distinguir alguns traços gerais e mesmo certos dados preciosos". SAUSSURE, F. Curso de lingüística geral, 2006, p. 263-264.

${ }^{30}$ HEIDEGGER, M. Ser e tempo, 2000, p. 65.
} 
abrangendo a obra Arqueologia do saber, de 1969. No entanto, com base na análise da linguagem, há razões para acreditar na existência de, ao menos, dois entendimentos desse conceito e, examinando-os à frente, pretenderemos demonstrar que a obra de 1969 pertence, na verdade, a um novo desafio. Há uma ruptura conceitual importante nesse episódio. A arqueologia não se restringe a nenhuma "fase", pois ocupará sempre um lugar importante nas investigações de Foucault. O que é preciso reconhecer é as transformações conceituais que há em sua unidade.

Vimos nos trabalhos sobre a interpretação algumas considerações a respeito da psicanálise e da fenomenologia, que, por fim, adquirem um aspecto circular. Mais do que um bloco homogêneo, os recortes testemunham que diferentes análises reportam-se umas às outras dentro de um espaço com características específicas. Entre 1953 e 1967, alguns elementos retornam, por exemplo, o símbolo e o indício, mas o que eles têm a dizer, a posição que ocupam não permanece estável. Além disso, se estabelecêssemos outro prisma de análise, por exemplo, a posição com relação à antropologia, veríamos que o recorte já estaria antes disso vencido. Enquanto, em 1953, Foucault admite a proposta de Biswanger de incorporar à fenomenologia o estudo antropológico, em As palavras e as coisas, de 1966, ele afirma que: "Daí nasceram todas as quimeras dos novos humanismos, todas as facilidades de uma 'antropologia', entendida como reflexão geral, meio positiva, meio filosófica, sobre o homem" - surgimento recente que traria também o "reconforto" e o "apaziguamento" da promessa de seu desaparecimento ${ }^{31}$. Ou seja, a pertinência de qualquer recorte depende da temática a qual nos dedicamos. ${ }^{32}$ Tudo isso nos exige bastante cautela com uma leitura que seja confiante na divisão geral por fases.

Feito o alerta, o caminho percorrido permite-nos produzir um primeiro esboço da topologia não da obra, mas das questões acerca da linguagem que habitam nela. Mas é preciso atar melhor essas pontas, pois ainda não devemos satisfazer-nos com o esclarecimento de dois problemas: a posição do intérprete e a interpretação infinita - condições então fundamentais para o sistema no qual, de acordo com Foucault, inserimonos desde o século XIX, com a crise da metafísica.

Em 1953, Foucault busca uma linguagem que seja "expressão". Ele afirma: "Poderíamos nos surpreender de a fenomenologia não se ter jamais desenvolvido no sentido de uma teoria da expressão. [...] Sem dúvida, uma filosofia da expressão não é possível senão em uma ultrapassagem

\footnotetext{
${ }^{31}$ FOUCAULT, M. As palavras e as coisas, 2002, p. XXI.

${ }^{32}$ Para a investigação da lida de Foucault com o problema antropológico, é importante interpor à análise a leitura da tese de doutorado complementar do filósofo: Introduction à l'anthropologie de Kant.
} 
da fenomenologia." ${ }^{33} \mathrm{Na}$ verdade, vê-se em Ser e tempo, no capítulo "O conceito preliminar de fenomenologia", um cuidado de Heidegger que contraria tal afirmação, qual seja: "afastar toda determinação que não seja demonstrativa." ${ }^{34} \mathrm{Se}$, por um lado, Foucault tem razão ao apontar que a fenomenologia, ao menos em Ser e tempo, sustenta a história sobre a analítica do Dasein, não é certo, por outro lado, que se trate de uma filosofia da interioridade, considerando que o discurso (Logos, de fenomeno-logia) consiste em "deixar e fazer ver", demonstrativamente, o fenômeno para "todos aqueles que discursam uns com os outros". ${ }^{35}$ Em suma, a fenomenologia pressupõe o amparo de cada existência, mas ela não se encerra na interioridade, e sim na comunhão de discursos direção em que um dia encaminhar-se-á, aliás, o próprio Foucault. No texto de 1953, inclusive não fica muito claro o que ele próprio entende por expressão. Ele chega a dizer: "Deixemos de lado, por agora, a análise da expressão, reservando-a a estudos ulteriores." ${ }^{36}$ Seria possível encontrar uma resposta quatorze anos mais tarde no colóquio "Nietzsche, Freud, Marx"? Nele, vemos, senão diretamente uma teoria da expressão, ao menos um tratamento da linguagem que é, neste sentido, bastante esclarecedor, e cuja formulação é, aliás, primorosa. Foucault afirma que a linguagem sempre fez nascerem dois tipos de pressupostos:

- inicialmente, a suspeita de que a linguagem não diz exatamente o que ela diz. O sentido que se apreende, e que é imediatamente manifesto, é talvez, na realidade, apenas um sentido menor, que protege, restringe e, apesar de tudo, transmite um outro sentido, sendo este, por sua vez, o sentido mais forte e o sentido 'por baixo'. É isso que os gregos chamavam de allegoria e hypinoïa.

- por outro lado, a linguagem faz nascer esta outra suspeita: que, de qualquer maneira, ela ultrapassa sua forma propriamente verbal, que há certamente no mundo outras coisas que falam e não são linguagem. Afinal, é possível que a natureza, o mar, o sussurro das árvores, os animais, os rostos, as máscaras, as facas cruzadas, tudo isso fale; talvez haja linguagem se articulando de uma maneira que não seria verbal. Isso seria, se vocês querem, muito grosseiramente, o semaïnon dos gregos. ${ }^{37}$

Insinua-se na análise de 1967, situada entre dois entendimentos da arqueologia, a que se seguirá em 1969, em $A$ arqueologia do saber. Foucault expõe aqui o trabalho que ele realizou e aquele que, depois de

\footnotetext{
${ }^{33}$ FOUCAULT, M. "Introdução (in Biswanger)" em Ditos e escritos, v. 1, 2010, p. 85.

${ }^{34}$ HEIDEGGER, M. Ser e tempo, 2000, p. 65.

${ }^{35}$ Ibid., p. 63.

${ }^{36}$ FOUCAULT, M. "Introdução (in Biswanger)" em Ditos e escritos, v. 1, 2010, p. 117.

${ }^{37}$ Idem. "Nietzsche, Freud, Marx" em Ditos e escritos, v. 2, 2008, p. 40.
} 
todas as polêmicas em torno da publicação de As palavras e as coisas, de 1966, ele prepara-se para realizar. ${ }^{38}$

Encontramos, no primeiro caso, apresentado como modelo alegórico, tanto o indício quanto o símbolo - o gênero sob a ameaça constante de que a imagem não seja senão um simulacro, fundamentalmente porque se a alegoria dirige-se à linguagem e não ao mundo das ideias, por outro lado, ela mantém a estrutura bicompartida que permitiu a Platão utilizar-se de uma alegoria para apresentar a sua metafísica. Em determinado momento do colóquio de 1967, Foucault lembra que a interpretação fora um problema muito importante também para o século XVI, na forma de uma leitura das semelhanças. Há as boas e as más semelhanças. O simulacro é "a má semelhança, que repousa na dissensão entre Deus e o Diabo", ${ }^{9}$ ou podemos também dizer, entre a verdade e a mentira. Se o simbólico reúne, o diabólico planta a discórdia, divide, aparta. Diabólica é a dissimulação do simbólico; é a falsa reunião entre imagem e sentido, gesto que interdita um genuíno re-ligare, a experiência religiosa do reencontro dos homens com o criador e com a verdade. Sob uma perspectiva arqueológica, prevalece, até os nossos dias, a lei do simulacro, a qual torna diabólica a atração pelo simbólico. Contra a constante ameaça do simulacro, imagem e sentido prestam contas de seu encontro até as teorias produzidas no século XIX, mas findando sempre no fracasso. Tratava-se não apenas de "fazer falar a imagem", como de fazer com que falassem uma verdade a cada instante fugidia e que, simultaneamente, punha em marcha novos sistemas epistemológicos que não se reconheciam como modos de interpretação. Finalmente, o problema não reside na qualidade das teorias alegóricas, mas na pretensão de poder-se desvendar o laço entre imagem e sentido. Estranho destino traçado, portanto, muito antes do século XVI, pois símbolo e indício são instrumentos de teorias que jamais escaparam da referência longínqua à metafísica platônica, mais especificamente da "Alegoria da caverna" - a alegoria da alegoria.

No momento em que, no século XIX, a interpretação ressurge livre do critério teológico e da metafísica platônica - mais especificamente com Nietzsche, Freud e Marx -, o jogo entre interpretação e simulacro alterase. Não é a favor da verdade oculta, mas meramente contra o simulacro, ou seja, contra as armadilhas que capturaram a tradição, contra uma imagem que esconda o sentido e contra a pretensão de encontrá-lo, que a interpretação torna-se uma tarefa infinita. Porque toda imagem será

\footnotetext{
${ }^{38}$ A respeito dessa virada, mas com ênfase no que vem depois dela, sugerimos a leitura de nosso artigo "Foucault e o nascimento do discurso: o enunciado e o poder", previsto para ser publicado no volume 40 da revista Dissertatio.

${ }^{39}$ Ibid., p. 42.
} 
tomada pela desconfiança do simulacro no momento em que um sentido insinuar-se como original, não se trata mais de encontrar a sua verdade mais justa, de encontrar a correspondência exata entre imagem e sentido, mas principalmente de fugir da mentira, ao infinito.

\section{A linguagem e o discurso}

Vimos que a primeira forma de linguagem apresentada por Foucault, a alegórica, a que quer "fazer falar a imagem", comporta a passagem de uma conquista do sentido originário pela fenomenologia do indício para um sentido que, como na psicanálise, é, na verdade, disperso, fragmentado, incerto, e o qual poderíamos tratar apenas por um método de cotejo, por uma decifração que não fosse final, mas que ainda assim se lançasse nesse espaço indeterminado, produzindo "sobredeterminações" e permitindo-nos colher as suas "coincidências". Essencialmente, importa, para o fim do século XIX, menos o alcance do sentido originário do que a ideia, muito presente na psicanálise, de que "a linguagem não diz exatamente o que ela diz", e não dirá. Afinal, esgotou-se a procura pelo sentido original, mas não se esgotou, até esse momento, o modelo alegórico do divórcio entre imagem e sentido. Não se esgotou a procura.

Vemos, no segundo caso, um modelo não mais bicompartido, um modelo de pura imanência, no qual as imagens não expressam senão a si mesmas. Acreditamos que, de 1953 a 1967, há, no pensamento de Foucault, uma passagem de uma arqueologia fundada no primeiro modelo a uma arqueologia fundada no segundo, e cuja forma plena, embora aqui já insinuada, será revelada somente dois anos mais tarde, em $A$ arqueologia do saber.

A insatisfação com a fenomenologia de 1953 a 1967, revelada principalmente no segundo caso, baseia-se não tanto no problemático argumento de que lhe falta uma "teoria da expressão", mas em que tomar a existência como pedra de toque da linguagem seja removê-la do primeiro modelo, caracterizado pelo movimento infinitamente circular da interpretação. A fenomenologia é reconhecida por Foucault como um método que, no lugar de realizar-se no discurso entre os homens, impõe um fim para a interpretação, que é justamente o retorno ao começo individual, a uma consciência que vê nas coisas o resultado de sua própria existência, porque ela mesma é resultado de sua presença entre as coisas. ${ }^{40}$ Apenas Nietzsche, Freud e Marx recusariam tal síntese entre

\footnotetext{
${ }^{40}$ Como afirmará Foucault em 1957: "A fenomenologia estabeleceu o tema da compreensão sobre uma análise do sentido imanente a toda experiência vivida". FOUCAULT, M. "A psicologia de 1850 a 1950" em Ditos e escritos, v. 1, 2010, p. 140.
} 
o interno e o externo, o que significa também a permissão à interpretação de seguir ao infinito na profundidade da exterioridade. A respeito de Freud, por exemplo, Foucault agora afirma: "Freud não interpreta signos, mas interpretações." 41

Embora Foucault tenha sido capaz de reconhecer e apresentar dois modelos, porque a interpretação é entendida como tarefa infinita, aquele por ele admitido foi primordialmente o primeiro. Afinal, uma teoria da interpretação só é realmente necessária dentro de uma linguagem que pretendamos alegórica, na qual haja um pensamento da diferença entre imagem e sentido - a primeira, a imagem a menosprezar; e o segundo, o sentido a determinar-se um lugar. A posição estranha de Foucault no texto de 1967 consiste em que ele vislumbre um limiar sem cruzá-lo. Afinal, o segundo modelo, da expressão imanente, seria o quê, senão o da identidade possível entre imagem e sentido? Nele, não nos cabe "fazer falar a imagem", porque ela não falará senão aquilo que ela é. E então a interpretação cessará, atendo-se a uma dimensão que nada expressa tão bem quanto a imagem real do sonho no instante em que sonhamos e do arquivo quando redescoberto.

Não há naquele texto o que trate do segundo modelo por uma perspectiva positiva. Sua abordagem - negativa - surgirá do esgotamento ao acaso das interpretações infinitas.

Quanto mais longe vamos na interpretação, ao mesmo tempo mais nos aproximamos de uma região absolutamente perigosa, na qual a interpretação vai encontrar não só seu ponto de retrocesso, mas onde ela própria vai desaparecer como interpretação, ocasionando talvez o desaparecimento do próprio intérprete. A existência sempre aproximativa do ponto absoluto da interpretação seria, simultaneamente, a aproximação de um ponto de ruptura. ${ }^{42}$

As rupturas que vemos, por exemplo, em As palavras e as coisas, não se dão pelo respeito à fala imanente dos arquivos, mas pelo esforço decifratório da interpretação. Foucault responde, em 1967, aos ataques dirigidos a esta obra, quando lhe indagam como reconhecer o ponto de ruptura exato em que uma época desfaz-se em outra. Tratava-se, então, de dizer que o problema não era o de estar-se absolutamente certo dos marcos da história, de ter tudo decifrado, mas de dizer que, embora não tenhamos todos os acessos, a interpretação poderia, dentro de um quadro específico, seguir ao infinito, a não ser que queira avançar ou recuar no tempo, descobrindo-se confrontada com rupturas, descontinuidades e, em

\footnotetext{
${ }^{41}$ FOUCAULT, M. "Nietzsche, Freud, Marx" em Ditos e escritos, v. 2, 2008, p. 47.
}

${ }^{42}$ Ibid., p. 45. 
nossa época, possivelmente confrontada com o próprio desaparecimento do homem, o intérprete.

Alguns anos mais tarde, em 1969, Foucault caminhará em direção a um novo entendimento de expressão - entendimento buscado desde 1953. No lugar da interpretação como expressão dos sentidos encobertos pela imagem, Foucault tratará de expressões imanentes, positivas, nas quais os objetos expressam-se a si mesmos ou são simplesmente constituídos pelo que é dito, a despeito das querelas com o divino. Tudo isto concernirá a um novo projeto, em $A$ arqueologia do saber, embora homônimo: "A arqueologia descreve os discursos como práticas específicas no elemento do arquivo." 43 O que é o arquivo senão a imagem expressiva que diz tudo o que tem a dizer, sem nada esconder depois de já ter estado obstruída pelo esquecimento?

Se em 1967 ainda não está totalmente claro, em 1969, veremos que o segundo modelo proposto sobre a linguagem, na qual ela é pura imanência, não diz respeito a fazer falar a fauna e a flora, tudo isso cuja linguagem é não verbal; trata-se de encontrar a imanência da palavra na imagem das práticas que a produziram.

Encontramos, assim, o plano de $A$ arqueologia do saber. Mais do que um livro de esclarecimentos metodológicos do trabalho até então empreendido em livros anteriores; mais do que aprofundar os rumos da interpretação infinita, Foucault toma distância do escopo até aqui discriminado. $\mathrm{O}$ verbo norteador agora é descrever e não mais decifrar. Na seguinte passagem de Arqueologia do saber, fica clara a diferença entre as duas formas de arqueologia, mesmo que tal cisão no interior de seu pensamento não tenha sido jamais admitida pelo filósofo:

Interpretar é uma maneira de reagir à pobreza enunciativa e de compensá-la pela multiplicação do sentido; uma maneira de falar a partir dela e apesar dela. Mas analisar uma formação discursiva é procurar a lei de sua pobreza, é medi-la e determinar-lhe a forma específica. É, pois, em um sentido, pesar o "valor" dos enunciados. Esse valor não é definido por sua verdade, não é avaliado pela presença de um conteúdo secreto; mas caracteriza o lugar deles, sua capacidade de circulação e de troca, sua possibilidade de transformação, não apenas na economia dos discursos, mas na administração, em geral, dos recursos raros. Assim concebido, o discurso deixa de ser o que é para a atitude exegética: tesouro inesgotável de onde se podem tirar sempre novas riquezas, e a cada vez imprevisíveis; providência que sempre falou antecipadamente e que faz com que se ouça, quando se sabe escutar, oráculos retrospectivos; ele aparece como um bem - finito, limitado, desejável, útil - que tem suas

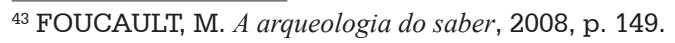


regras de aparecimento e também suas condições de apropriação e de utilização; um bem que coloca, por conseguinte, desde sua existência (e não simplesmente em suas "aplicações práticas"), a questão do poder; um bem que é, por natureza, o objeto de uma luta, e de uma luta política. ${ }^{44}$

Não mais a arqueologia de tipo psicanalítica e saussuriana da "decifração dos códigos secretos" - ou, como em As palavras e as coisas, dos "códigos fundamentais", dos "códigos primordiais", dos "códigos ordenadores", formadores da "rede secreta" que é tomada como "ordem", como o problemático e polêmico "solo positivo". ${ }^{45}$ Não mais a arqueologia que interpreta interpretações e não mais a interpretação infinita que se depara de súbito com rupturas. Trata-se aqui, contra não só a metafísica, mas também contra a estrutura alegórica de pensamento, de dedicar-se à mera expressividade; trata-se de "analisar uma formação discursiva" conforme novo critério de positividade, a do discurso e não a da linguagem.

\section{Referências}

FOUCAULT, M. "A psicologia de 1850 a 1950". In: Ditos e escritos, v. 1. Tradução de Vera Lucia Avelar Ribeiro. Rio de Janeiro: Forense universitária, 2010.

. "Introdução (in Biswanger)". In: Ditos e escritos, v. 1. Tradução de Vera Lucia

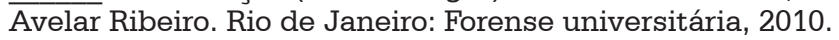

. "Nietzsche, Freud, Marx". In: Ditos e escritos, v. 2. Tradução de Elisa Monteiro. Rio de Janeiro: Forense Universitária, 2008.

. A arqueologia do saber. Tradução de L. F. B. Neves. Rio de Janeiro: Forense Universitária, 2008.

2002.

. As palavras e as coisas. Tradução de S. T. Muchail. São Paulo: Martins Fontes,

Introduction à l'anthropologie. Paris: VRIN, 2009.

FREUD, S. "A interpretação dos sonhos". In: Obras psicológicas completas de Sigmund Freud, v. V. Tradução de W. I. Oliveira. Rio de Janeiro: Imago, 1973.

. "Simbolismo nos sonhos". In: Obras psicológicas completas de Sigmund Freud, v. XV. Tradução de J. Salomão. Rio de Janeiro: Imago, 1973.

HEGEL, G. "Les introductions manuscrites". In: Introduction à la philosophie de l'histoire. Tradução de M. Bienenstock e N. Waszek. Paris: Les livres de poche, 2011.

. Fenomenologia do espírito. Tradução de P. Meneses. Petrópolis, RJ: Vozes, 2002.

HEIDEGGER, M. A caminho da Linguagem. Tradução de M. S. C. Schuback. Petrópolis, RJ: Vozes, 2004.

\footnotetext{
${ }^{44}$ Ibid., p. 136-137.

${ }^{45}$ FOUCAULT, M., As palavras e as coisas, 2002, p. XVI-XVII.
} 
T. M. S. Prado - O sonho da interpretação na arqueologia de Foucault

HEIDEGGER, M. Ser e tempo. Tradução de M. S. C. Schuback, Petrópolis, RJ: Vozes, 2000.

LACAN, J. "Função e campo da fala e da linguagem", In: Escritos. Tradução de V. Ribeiro. Rio de Janeiro: Zahar, 1998.

. O Seminário, livro 1 Os escritos técnicos de Freud. Tradução de Betty Milan. Rio de Janeiro: Zahar, 1983.

SAUSSURE, F., Curso de lingüística geral. São Paulo: Cultrix, 2006.

\section{Endereço postal:}

Programa de Pós-Graduação em Filosofia

Universidade São Judas Tadeu (USJT)

Rua Taquari, 546, Bl.C, $2^{\circ}$ andar - Mooca

03166-000 São Paulo, SP, Brasil

Data de recebimento: 10/09/2013

Data de aceite: 26/05/2014 